\title{
PENERAPAN MODEL PEMBELAJARAN ROLE PLAY PADA MATA PELAJARAN PENGOLAHAN DAN PENYAJIAN MAKANAN KONTINENTAL UNTUK MENINGKATKAN AKTIVITAS DAN HASIL BELAJAR SISWA
}

\author{
I Gusti Ayu Made Sukelasmini \\ SMK Negeri 2 Singaraja \\ Email: sukelasmini@gmail.com
}

\begin{abstract}
ABSTRAK
Penelitian ini bertujuan untuk mengetahui peningkatan aktivitas dan hasil belajar siswa kelas XI A 5 SMK Negeri 2 Singaraja Tahun Pelajaran 2017/2018 setelah diterapkannya model pembelajaran role play pada mata pelajaran pengolahan dan penyajian makanan kontinental. Penelitian ini adalah penelitian tindakan kelas. Subjek dalam penelitian tindakan kelas ini adalah siswa kelas XI A 5 SMK Negeri 2 Singaraja semester genap tahun ajaran 2017/2018 yang berjumlah 36 orang yang terdiri dari 22 siswa laki-laki dan 14 siswa perempuan.. Sedangkan objeknya adalah motivasi dan hasil belajar siswa. Data motivasi belajar siswa dikumpulkan dengan lembar observasi, sedangkan data hasil belajar siswa dikumpulkan dengan tes pilihan ganda. Analisis data yang digunakan pada penelitian ini menggunakan analisis data deskriptif. Berdasarkan penelitian yang telah dilakukan dapat disimpulkan bahwa penerapan model pembelajaran role play pada siswa kelas XI A 5 SMK Negeri 2 Singaraja Tahun Pelajaran 2017/2018 mata pelajaran pengolahan dan penyajian makanan kontinental dapat meningkatkan aktivitas belajar dan hasil belajar siswa. Hal ini dapat dilihat dari peningkatan hasil aktivitas belajar siswa yaitu 8 siswa atau $22 \%$ siswa berkatagori aktif, 21 siswa atau 58\% berkatagori cukup aktif, dan 7 siswa atau 20\% berkatagori kurang aktif. Pada siklus II menjadi 2 siswa atau 5.5\% siswa berkatagori sangat aktif, 22 siswa atau $61 \%$ berkatagori aktif, dan 12 siswa atau $33.5 \%$ berkatagori cukup aktif. Untuk rata- rata hasil belajar siklus I yaitu sebesar 79.29 dan siklus II meningkat sebesar 83.19.
\end{abstract}

Kata kunci: hasil belajar, model pembelajaran role play, motivasi belajar.

\begin{abstract}
The purpose of this study was to determine the increase in activity and learning outcomes of class XI A 5 students of SMK Negeri 2 Singaraja 2017/2018 Academic Year after the implementation of role play learning models in the subjects of processing and serving continental food. This research is a classroom action research. The subjects in this class action research were students of class XI A 5 of SMK Negeri 2 Singaraja in the even semester of the 2017/2018 academic year, totaling 36 people consisting of 22 male students and 14 female students. While the object was student motivation and learning outcomes. Data on student learning motivation was collected by observation sheet, while data on student learning outcomes were collected by multiple choice tests. Data analysis used in this study used descriptive data analysis. Based on the research that has been done, it can be concluded that the application of role play learning models in class XI A 5 of SMK Negeri 2 Singaraja Academic Year 2017/2018 subject to processing and serving continental food can improve learning activities and student learning outcomes. This can be seen from the increase in the results of student learning activities, namely 8 students or $22 \%$ of students in the active category, 21 students or $58 \%$
\end{abstract}


categorized as quite active, and 7 students or $20 \%$ categorized as less active. In cycle II it becomes 2 students or $5.5 \%$ of students are very active, 22 students or $61 \%$ are active categories, and 12 students or $33.5 \%$ are categorized as quite active. For the average learning outcomes of the first cycle that is equal to 79.29 and the second cycle increases by 83.19 .

Keywords: learning outcomes, role play learning models, learning motivation.

\section{PENDAHULUAN}

Pendidikan merupakan salah satu faktor penentu keberhasilan suatu bangsa, maka dari itu pemerintah sedang gencar- gencarnya melakukan berbagai upaya untuk meningkatkan mutu pendidikan. Salah satu upaya yang dilakukan adalah penyempurnaan kurikulum yang kita anut seperti sekarang ini yaitu kurikulum KTSP.Sebagai pedoman penyelenggaraan pendidikan, kurikulum merupakan acuan dalam menyelenggarakan pendidikan sekaligus sebagai tolok ukur pencapaian tujuan pendidikan.Tujuan pendidikan tersebut meliputi tujuan pendidikan nasional yang juga memiliki kesesuaian dengan kekhasan, kondisi dan potensi daerah, satuan pendidikan, dan siswa.

Dalam Standar Nasional Pendidikan Pasal 1, ayat 15 dikemukakan bahwa Kurikulum Tingkat Satuan Pendidikan (KTSP) adalah kurikulum operasional yang disusun dan dilaksanakan oleh masingmasing satuan pendidikan (BSNP, 2006). Kurikulum ini disusun dan dikembangkan oleh setiap satuan pendidikan berdasarkan standar isi (Peraturan Menteri Pendidikan Nasional Nomor 22 Tahun 2006) dan standar kompetensi lulusan (Peraturan Menteri Pendidikan Nasional Nomor 23 Tahun 2006). Standar isi dan standar kompetensi lulusan merupakan pedoman pengembangan KTSP untuk mewujudkan pencapaian tujuan pendidikan nasional.

SMK (Sekolah Menengah Kejuruan) dengan Program Keahlian Tata boga yang mempunyai tujuan mempersiapkan peserta didik agar menjadi manusia produktif, mampu bekerja mandiri, mengisi lowongan pekerjaan yang ada di industry sebagai tenaga kerja tingkat menengah sesuai dengan kompetensi dalam program studi keahlian pilihannya, ulet, gigih dalam berkompetensi, dan mampu mengembangkan diri di kemudian hari baik secara mandiri maupun melalui jenjang pendidikan yang lebih tinggi dan berkualitas.

Harapan ketika siswa lulus dari Sekolah Menengah Kejuruan (SMK) Program Keahlian Tata Boga adalah salah satu bagian dari SMK Pariwisata dimana lulusannya diharapkan memiliki pengetahuan dan keterampilan sehingga dapat memenuhi tujuan dari pada SMK itu sendiri. Dimana lulusannya diharapkan memiliki pengetahuan dan keterampilan sehingga dapat memenuhi persyaratan dalam bidang industri, bahkan mampu berusaha sendiri dalam membuka lapangan kerja. Berbagai upaya secara khusus telah dilaksanakan untuk mencapai hal tersebut, seperti perbaikan kuruikulum yang terus menerus yang dikembangkan, penerapan pendidikan sistem ganda dan menyediakan alat-alat praktek yang disesuaikan dengan kebutuhan, karena hakekatnya sekolah kejuruan berorientasi pada dunia kerja, meliputi pengetahuan dan keterampilan (skill) maka kualitasnya lulusannya adalah tolak ukur untuk memenuhi tuntutan lapangan.

Kenyataanya menunjukkan bahwa lulusan SMK kurang memiliki keterampilan untuk bekerja, lulusan SMK belum dapat sebagai penghasil tenaga kerja siap pakai (Slameto, 2010). Hal ini bisa disebabkan karena berbagai faktor, salah satunya dalam proses pembelajaran dikelas pada mata pelajaran pengolahan dan penyajian makanan kontinental.

Pengetahuan pengolahan dan penyajian makanan kontinental merupakan ilmu yang menerapkan keterampilan yang dimiliki siswa dalam mengolah berbagai hidangan kontinental dimulai dari appetizer sampai 
dessert dengan metode persiapan dan pengolahan serta menu yang berasal dari daratan Eropa dan Amerika. Makanan Kontinental adalah salah satu bidang studi yang ada di sekolah SMK Negeri 2 Singaraja, tujuan adanya bidang studi ini adalah untuk melatih keterampilan yang dimiliki siswa khususnya keterampilan dalam mengolah berbagai hidangan kontinental yang merupakan salah satu kompetensi keahlian yang harus dimiliki oleh siswa program keahlian Tata Boga.

Hasil belajar siswa pada mata pelajaran pengolahan dan penyajian makanan kontinental tergolong rendah karena dalam proses belajar, faktor keaktifan siswa sebagai subjek belajar sangat menentukan, padahal selama ini sering kita jumpai siswa itu hanya menyimak dan mendengarkan pelajaran dari seorang guru. Ini menjadikan kondisi yang tidak profesional, sehingga siswa menjadi pasif dan tidak kreatif.Bahkan terkadang masih saja ada anggapan bahwa siswa itu sebagai objek belajar.Sehingga siswa kurang mampu mengembangkan potensi dirinya.

Berdasarkan hasil observasi terhadap proses pembelajaran di kelas XI A 5 SMK Negeri 2 Singaraja dan wawancara dengan siswa yang sekaligus dengan pemberian angket, terungkap beberapa permasalahan yang dapat diidentifikasi adalah sebagai berikut.Pertama, berdasarkan angket yang disebarkan kepada siswa serta dari hasil observasi dikelas, 12 orang siswa menyatakan kurang menyiapkan diri untuk mengikuti pembelajaran di kelas walaupun mereka sudah mengetahui materi yang akan diajarkan oleh guru di kelas. Kedua, dalam proses pembelajaran minat siswa untuk belajar masih rendah, dan siswa cenderung pasif. Rendahnya aktivitas siswa untuk belajar ditunjukkan dari kurangnya perhatian siswa dalam kegiatan pembelajaran. Hal tersebut juga didukung dari penyebaran angket yang disebarkan pada 36 orang siswa kelas XI A 5 SMK Negeri 2 Singaraja, ditemukan 20 siswa menyatakan senang belajar pengolahan dan penyajian makanan kontinental jika mereka tertarik dengan materi yang diajarkan. Dengan demikian, untuk meningkatkan kualitas pembelajaran pengolahan dan penyajian makanan kontinental, maka harus didasarkan pada kebutuhan siswa dalam menyelesaikan berbagai permasalahan. Salah satu aspek penting dalam menyelesaikan permasalahan adalah aktivitas dalam belajar.

Menyikapi permasalahan di atas, maka diperlukan suatu model pembelajaran yang tepat untuk meningkatkan aktivitas dan hasil belajar siswa.Melihat hasil pengamatan peneliti di lapangan mengenai aktifitas dan hasil belajar pengolahan dan penyajian makanan kontinental siswa di kelas XI A 5 SMK Negeri 2 Singaraja, serta memperhatikan keunggulan-keunggulan yang dimiliki model pembelajaran Role play maka akan mencoba menerapkan model pembelajaran Role play dalam proses pembelajaran di kelas.Model pembelajaran role playing atau bermain peran ini merupakan pembelajaran yang lebih menekankan pada permainan gerak dan siswa biasanya di latih untuk memahami, memperagakan setiap peran - peran yang di perankannya untuk selanjutnya biasanya siswa di tugaskan untuk memberikan penilaian baik kekurangan atau kelebihan dari peran yang dimainkan ataupun juga jalan cerita yang di perankannya. Selain penialaian terhadap peran, penilaian terhadap jalan cerita dalam role playing tersebut biasanya di jadikan bahan refleksi dalam model pembelajaran role playing misalnya menentukan apa isi dari cerita tersebut, hikmah yang di dapat dalam ceritanya dan lain- lain.

Nama lain dari pembelajaran role playing ini adalah Sosiodrama. Sosiodrama (Role playing) oleh Djamarah (2011:213) berasal dari kata Sosio dan drama.Sosio berarti sosial menunjuk pada objeknya yaitu masyarakat menunjukan pada kegiatankegiatan sosial, dan drama berarti mempertunjukan, mempertontonkan atau memperlihatkan.Jadi sosiodrama adalah metode mengajar yang dalam pelaksanaannya peserta didik mendapat tugas dari guru untuk mendramatisasikan suatu situasi sosial yang mengandung suatu problem, agar peserta didik dapat memecahkan suatu masalah yang muncul dari suatu situasi sosial. Role playing dapat dikatakan sama artinya dan dalam 
proses pemakaiannya sering disilih gantikan. Sosiodrama pada dasarnya mendramatisasikan tingkah laku dalam hubungannya dengan masalah sosial.

Berdasarkan uraian di atas, maka peneliti mencoba menerapkan suatu model pembelajaran yang dapat menuntun siswa untuk memperbaiki proses belajar dalam meningkatkan aktivitas siswa dalam belajar, serta untuk mengatasi permasalahanpermasalahan yang muncul di kelas tersebut selama peneliti melakukan observasi, maka peneliti mengajukan penelitian yang berjudul "Penerapan Model Pembelajaran Role play pada Mata Pelajaran Pengolahan dan penyajian makanan kontinental untuk Meningkatkan Aktivitas dan Hasil Belajar Siswa Kelas XI A 5 SMK Negeri 2 Singaraja Tahun Pelajaran 2017/2018”.

\section{METODE PENELITIAN}

Jenis penelitian yang dilaksanakan adalah penelitian tindakan kelas (PTK) atau classroom action research pada tahun ajaran 2017/2018 dengan menerapkan model pembelajaran role play yang bertujuan untuk memperbaiki pembelajaran di kelas berdasarkan pada permasalahan yang ditemukan pada saat observasi awal, penelitian ini juga bertujuan untuk dapat meningkatkan aktivitas dan hasil belajar mata pelajaran Pengolahan dan penyajian makanan kontinental siswa kelas XI semester genap SMK Negeri 2 Singaraja. Penelitian tindakan kelas ini, dilaksanakan dalam tiga siklus seperti terlihat sebagai berikut.

Masing-masing siklus terdiri dari empat tahapan yaitu: (1) perencanaan, (2) implementasi tindakan, (3) observasi, dan (4) refleksi (Ghony, 2008:12). Dalam penyusunan PTK tahapan-tahapan pelaksanaan penelitian tindakan kelas yang akan dilaksanakan pada setiap siklusnya secara umum dapat dijabarkan sebagai berikut.

a) Tahap 1 Perencanaan

1) Menetapkan pendekatan atau model pembelajaran yang akan digunakan.

2) Menyusun persiapan mengajar sesuai dengan kompetensi dasar dan indikator (RPP).
3) Menyiapkan buku paket dan penunjang.

4) Menyusun permasalahan yang akan dipecahkan oleh siswa.

5) Menyiapkan media/ alat peraga sederhana yang akan digunakan

6) Menyiapkan instrumen pengumpulan data.

7) Menyiapkan kunci jawaban.

b) Tahap 2 Implementasi Tindakan 1

Tindakan yang dilaksanakan pada tahap pelaksanaan sesuai dengan perencanaan yang telah disusun berdasarkan pada langkahlangkah pembelajaran dengan menggunakan model pembelajaran role play.

\section{c) Tahap 3 Observasi}

Kegiatan yang dilakukan pada tahap ini adalah melakukan observasi terhadap suasana belajar dan motivasi belajar siswa selama proses pembelajaran dilaksanakan serta mengumpulkan data hasil belajar siswa dengan menggunakan metode tes yang diberikan setiap akhir siklus.

\section{d) Tahap 4 Refleksi}

Setelah dilaksanakan evaluasi pada siklus I, tindakan yang dilaksanakan pada siklus sebelmunya dikaji dan direfleksi dengan tujuan apabila belum mencapai hasil yang diharapkan maka dicari penyebabnya, kemudian dipikirkan bersama untuk mengatasi hambatan yang dialami sebagai rencana baru pada siklus berikutnya. Secara keseluruhan dapat dilihat pada bagan berikut. 


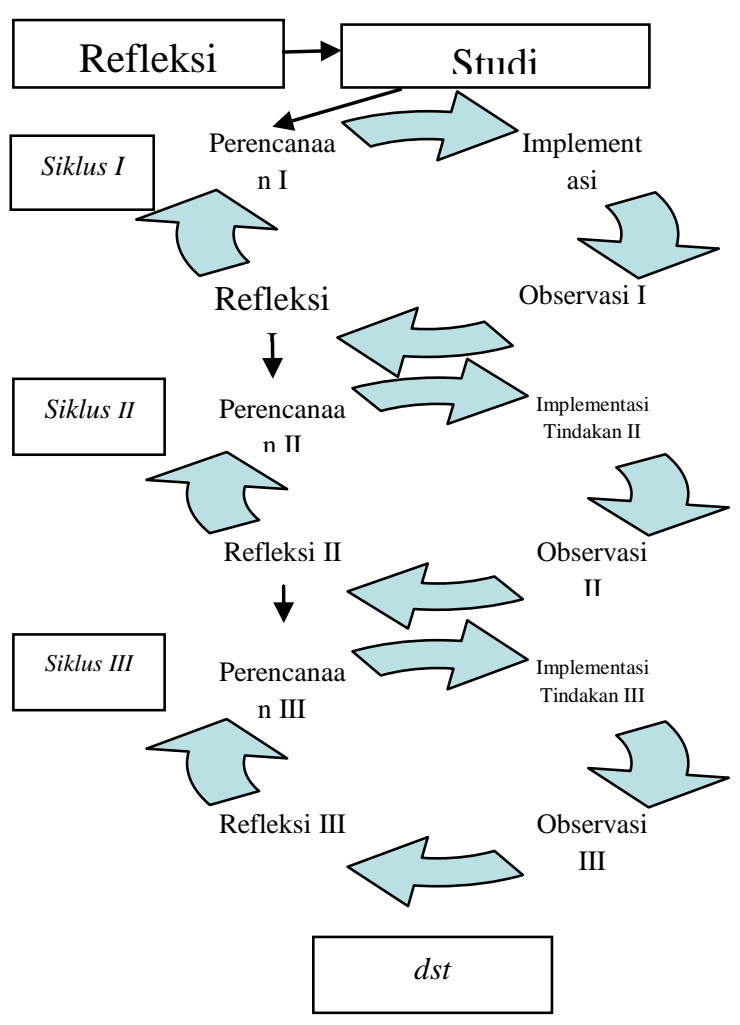

Gambar 1. Bagan Rancangan Penelitian

Penelitian ini akan dilaksanakan dalam waktu 3 bulan yaitu dari bulan februari 2018 sampai bulan april 2018. Penelitian ini dilaksanakan pada siswa kelas XI A 5 SMK Negeri 2 Singaraja semester genap tahun ajaran 2017/2018 yang berjumlah 36 orang yang terdiri dari 22 siswa laki-laki dan 14 siswa perempuan.

Data-data yang dikumpulkan untuk mengetahui aktivitas proses belajar siswa dalam penelitian ini menggunakan lembar observasi aktivitas belajar siswa dengan memperhatikan indikator yang tampak.

Data-data yang dikumpulkan untuk mengetahui hasil belajar siswa dalam penelitian ini, menggunakan bentuk tes objektif sebanyak 20 butir soal untuk setiap akhir siklus.

data pada penelitian ini dianalisis menggunakan analisis statistik deskriptif. Kriteria ketuntasan pada penelitian ini adalah minimal skor siswa berada pada katagori aktif dan hasil belajar yang diperoleh siswa minimal 80 sesuai KKM yang ditetapkan oleh sekolah.

\section{HASIL DAN PEMBAHASAN Hasil Penelitian}

Penelitian tindakan kelas ini dilaksanakan di kelas XI A 5 SMK N 2 Singaraja Tahun Pelajaran 2017/2018, dengan subjek sebanyak 36 orang. Materi pelajaran yang dibelajarkan adalah pengolahan hidangan utama dari daging yang dikemas menjadi dua siklus. Setiap siklus dirinci menjadi tiga kali pertemuan. Siklus I dikemas dalam 2 rencana pelaksanaan pembelajaran (RPP) yang dilaksanakan dalam 2 kali pertemuan tatap muka. Siklus II dikemas dalam 2 rencana pelaksanaan pembelajaran (RPP), yang dilaksanakan dalam 2 kali pertemuan dan 1 kali pertemuan untuk tes hasil belajar.

Berdasarkan hasil penelitian yang telah dilaksanakan selama dua siklus menunjukkan adanya peningkatan terhadap aktivitas belajar dan hasil belajar siswa, melalui penerapan role play dalam pembelajaran pengolahan dan penyajian makanan kontinental di kelas XI A5 SMK Negeri 2 Singaraja Tahun Pelajaran 2017/2018.

Hasil penelitian yang telah dilaksanakan selama 2 siklus adalah sebagai berikut. Siklus I aktivitas belajar siswa yaitu 8 siswa atau $22 \%$ siswa berkatagori aktif, 21 siswa atau $58 \%$ berkatagori cukup aktif, dan 7 siswa atau $20 \%$ berkatagori kurang aktif. Dan untuk hasil belajar siklus I yaitu sebanyak 25 orang siswa atau $69.00 \%$ dinyatakan tuntas, dan sisanya yaitu 11 orang siswa atau $31.00 \%$ telah dinyatakan belum memenuhi standar ketuntasan. Dengan demikian ketuntasan hasil belajar siswa pada siklus I baru mencapai 69.00. \%.

\section{Pembahasan Hasil Penelitian}

Dalam proses pembelajaran Guru dan siswa belum terbiasa menerapkan model bermain peran dalam pembelajaran, siswa masih canggung dan malu dalam memerankan tokoh yang diperankann, konsentrasi siswa masih kurang, hal ini terlihat ketika bermain peran maupun mengerjakan soal evaluasi, siswa masih ada yang menengok ke kiri dan kanan maupun ke belakang, siswa masih kurang keberanian dalam mengemukakan penilaian, pendapat dan komentarnya, daya 
tangkap materi pembelajaran masih belum optimal dibuktikan dengan masih adanya beberapa orang yang mengalami kesulitan dalam mengerjakan soal evaluasi, suasana senang dalam belajar sudah tampak, meski masih ada siswa yang terlihat kurang bersemangat.

Berdasarkan perbaikan yang telah dilakukan, aktivitas belajar pada siklus II dan hasil pembelajaran yang diperoleh pada siklus II ini menunjukkan adanya peningkatan. Aktivitas belajar siswa diperoleh 2 siswa atau $5.5 \%$ siswa berkatagori sangat aktif, 22 siswa atau $61 \%$ berkatagori aktif, dan 12 siswa atau $33.5 \%$ berkatagori cukup aktif. Sedangkan untuk hasil belajar diperoleh data sebagai berikut: sebanyak 33 orang siswa atau $91.00 \%$ dinyatakan tuntas, dan sisanya yaitu 3orang siswa atau $9.00 \%$ telah dinyatakan belum memenuhi standar ketuntasan. Dengan demikian ketuntasan hasil belajar siswa pada siklus II sudah mencapai 91\%. Berdasarkan data tersebut dapat dinyatakan sudah terjadi peningkatan aktivitas dan hasil belajar siswa yang menggunakan model pembelajaran role play pada mata pelajaran pengolahan dan penyajian makanan kontinental.

Hal ini disebabkan karena semua siswa bersemangat sekali ketika guru masuk ke kelas dan mengungkapkan kepada mereka akan bermain peran kembali dengan topik yang berbeda, guru tidak merasa kesulitan kembali untuk mengarahkan siswa dalam berkelompok, sehingga energi yang digunakan untuk mengatur siswa tidak terlalu banyak. respon siswa yang positif memudahkan guru memberikan penerangan tentang peran yang harus dilakukan masingmasing siswa, siswa yang bermain peran kelihatan tidak canggung lagi, mereka lepas (tidak ada beban) dalam memerankan perannya. siswa lebih tertib dan tenang dalam mengerjakan lembaran evaluasi, jumlah siswa yang merasa kesulitan dalam mengerjakan lembaran evaluasi menurun, siswa lebih cepat menyelesaikan lembaran evaluasi dibandingkan dengan mengerjakan lembaran yang sama seperti pada siklus tindakan perasaan guru lebih bahagia sebab hampir semua siswa mampu mengerjakan lembaran evaluasi dengan baik dan tepat waktu.
Perbandingan hasil aktivitas belajar siklus I dan II adalah sebagai berikut.

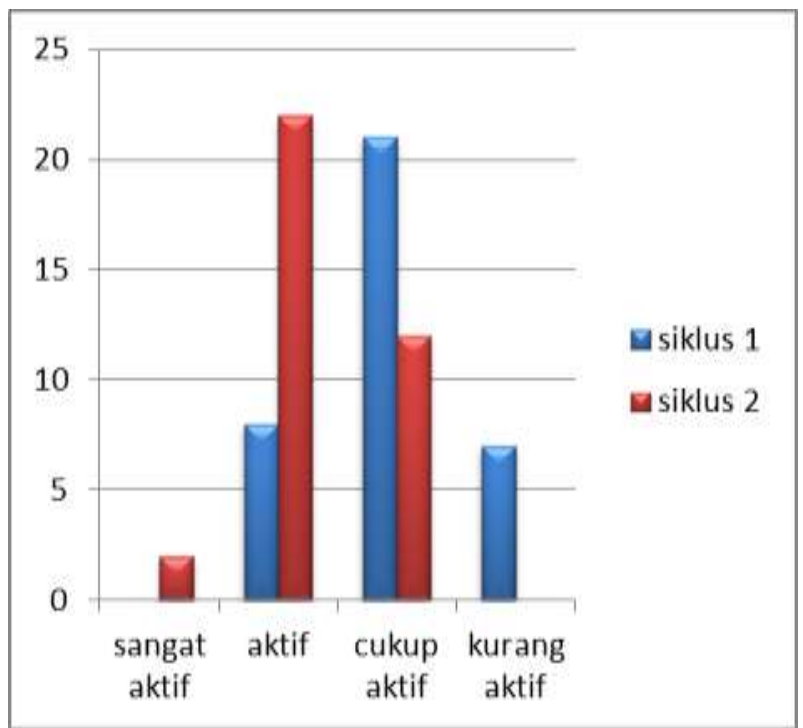

Gambar 2. Perbandingan Aktivitas Belajar Siswa

Sedangkan perbandingan hasil belajar siklus I dan II adalah sebagai berikut.

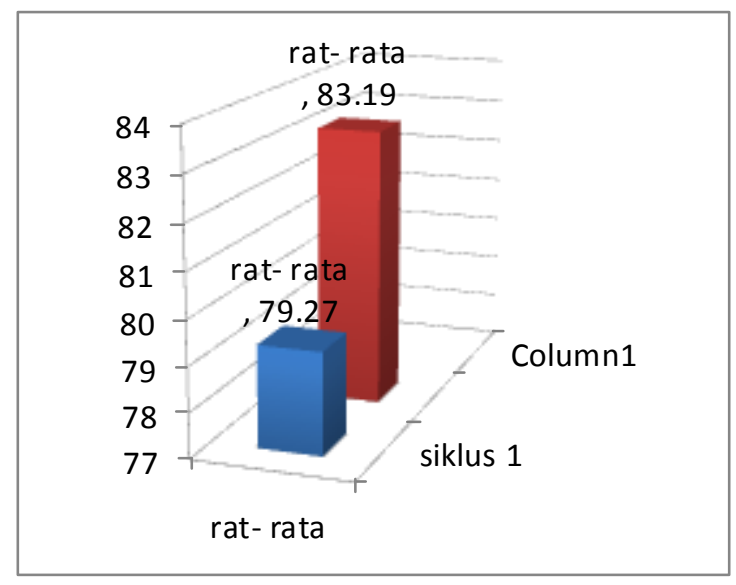

Gambar 3. Perbandingan Hasil belajar Siswa

\section{PENUTUP \\ Simpulan}

Berdasarkan hasil penelitian dan pembahasan yang telah diuraikan, dapat disimpulkan penerapan model pembelajaran role play pada siswa kelas XI A 5 SMK Negeri 2 Singaraja Tahun Pelajaran 2017/2018 mata pelajaran pengolahan dan penyajian makanan kontinental dapat meningkatkan aktivitas belajar dan hasil belajar siswa. Hal ini dapat dilihat dari 
peningkatan hasil aktivitas belajar siswa yaitu 8 siswa atau $22 \%$ siswa berkatagori aktif, 21 siswa atau $58 \%$ berkatagori cukup aktif, dan 7 siswa atau $20 \%$ berkatagori kurang aktif. Pada siklus II menjadi 2 siswa atau $5.5 \%$ siswa berkatagori sangat aktif, 22 siswa atau $61 \%$ berkatagori aktif, dan 12 siswa atau $33.5 \%$ berkatagori cukup aktif. Untuk rata- rata hasil belajar siklus I yaitu sebesar 79.29 dan siklus II meningkat sebesar 83.19.

\section{Saran}

Saran yang dapat diajukan dari diadakannya penelitian ini adalah sebagai berikut: 1) Siswa hendaknya selalu bersemangat dalam belajar, sehingga cepat memahami materi yang diberikan oleh guru, 2) Guru disarankan untuk menggunakan pembelajaran yang inovatif di kelas, agar siswa merasa senang dan nyaman dalam pembelajaran, dan 3) Peneliti lain disarankan untuk mengembangkan penelitian ini agar kendala atau permasalahan yang terjadi pada proses pembelajaran dapat diminimalkan.

\section{DAFTAR RUJUKAN}

BSNP. 2006. Permendiknas RI No. 22 Tahun 2006 tentang Standar Isi untuk Satuan Pendidikan Dasar dan Menengah. Jakarta.

Baroroh, K., 2011. Upaya meningkatkan nilainilai karakter peserta didik melalui penerapan metode role playing. Jurnal Ekonomi \& Pendidikan, 8(2).

Djamarah, Syaiful Bahri. 2011. Psikologi Belajar. Jakarta : Rineka Cipta.

Ghony, M. Djunaidi. 2008. Penelitian Tindakan kelas. Malang: UIN-.

Fatmaningsih, Z., Sugiharto, D.Y.P. and Hartati, M.T.S., 2018. Meningkatkan Sikap Disiplin Berlalu Lintas Melalui Layanan Bimbingan Kelompok Dengan Teknik Role Playing. Indonesian Journal of Guidance and Counseling: Theory and Application, 7(1).

Khairani, R., Lipoeto, N. I., \& Ristiono, B. (2018). Perbandingan Efektifitas Penyuluhan Kesehatan Gigi Metode Dongeng (Storytelling) Dengan Metode Bermain Peran (Role Play) Pada Siswa
Kelas 3 Sekolah Dasar. Andalas Dental Journal, 5(1).

Lestari, E.D., 2018. Manajemen Persekolahan: Pengembangan Song, Word Map, Game dan Role Play Dalam Pembelajaran Bahasa Inggris Untuk Meningkatkan Speaking Skill Dan Keterlibatan Siswa Kelas III SD Kristen Pelita Bangsa Lumajang. Manajemen Bisnis Kompetensi, 13(1).

Romadhona, F.T. and Yundra, E., 2018. Pengembangan Edugame Sebagai Media Pembelajaran Berbasis Role Play Game (Rpg) Pada Mata Pelajaran Simulasi Digital Kelas X Tav Di Smkn 3 Surabaya. Jurnal Pendidikan Teknik Elektro, 7(2).

Slameto. 2010. Belajar dan Faktor yang mempengaruhinya. Jakarta: Rineka. Cipta.

Yulia Siska. 2010. Penerapan Metode Bermain Peran (Role Playing) Dalam Meningkatkan Keterampilan Sosial dan Keterampilan Berbicara Anak Usia Dini Taman Kanak-kanak Al-Kautsar. Bandar Lampung. Peneltian Tindakan Kelas.

Yohana, F.M., Pratiwi, H.A. and Susanti, K., 2019. Penerapan Metode Role Play Storytelling dengan Menggunakan Media Poster Pada Kemampuan Berbahasa Inggris Mahasiswa Desain Komunikasi Visual. Magenta| Official Journal STMK Trisakti,3(1), pp.397408.

Zaki, R., Werdati, S. and Dewi, F.S.T., 2009. Efektivitas Role Play, penayangan VCD dan modul dalam meningkatkan keterampilan komunikasi terapeutik mahasiswa Stikes Jenderal Ahmad yani Yogyakarta. Berita Kedokteran Masyarakat, 25(3), p.125. 